\title{
HERBERT JOSEPH SPINDEN
}

(1879-1967)

Por Alberto Ruz LHUillieR

Centro de Estudios Mayas UNAM.

Con la muerte de Herbert J. Spinden, puede decirse que desapareció toda una época de la investigación en el campo de los estudios mayas, época de importancia trascendental, de la que Spinden llegó a ser un superviviente. Esa época se había inciado en los últimos años del siglo pasado con valiosos investigadores como: Maudslay, Förstemann, Holmes, Schellhas, Bowdith y Goodman; había proseguido con Seler y Maler; y sus últimos representantes fueron Morley, Tozzer y el mismo Spinden. Fue la época en que la arqueología mesoamericana - la maya en particular - entró en una vía seria, deśpués de salir de la fase romántica en que los vestigios de las civilizaciones desaparecidas eran motivos de emocionantes relatos de viajes y aventuras, sazonados con lucubracionse generalmente sobrantes de fantasía.

Al revisar la bibliografía de Spinden, vemos que tocó muchos aspectos de la investigación: estética, arqueología, cronología, epigrafía, astronomía, lingüística, religión. La obra que presentó en 1913 como tesis de doctorado, A Study of Maya Art, pese a que muchas de sus ideas hayan sido superadas, no deja de ser clásica e indispensable para el arqueólogo o el historiador de arte interesado en lo maya.

Sin embargo, quizá la más valiosa aportación de Spinden a los estudios mayistas haya sido la correlación que estableció entre el calendario maya y el nuestro, correlación que presentó en forma sintética en 1919 y que explicó en detalles, comparándola con otros intentos de relacionar ambos calendarios, en su obra The Reduction of Mayan Dates (1924). Después de haber sido aceptada y utilizada durante algún tiempo, su correlación quedó desplazada por la que había establecido antes que él Goodman, y que afinaron después Martínez Hernández y Thompson. En la actualidad, el problema de la correlación maya-cristiana no puede considerarse resuelto, 
y en los últimos años, cierto número de investigadores ha vuelto a dar preferencia a la de Spinden.

Spinden participó en varias exploraciones arqueológicas en América Central; también había hecho trabajos de campo en arqueología y etnología de Dakota del Norte e Idaho para el Peabody Museum de Harvard (1905-1908). Fue auxiliar de conservador en el American Museum of Natural History, de New York (1909-1921); conservador de arqueología y etnología mexicanas en el Peabody Museum, de Harvard (1921-1929); conservador de antropología del Buffalo Museum of Art and Science, de New York (1926-1929); y finalmente conservador de Arte Indígena Americano y Culturas Primitivas, en el Brooklyn Museum, de New York (1929-1951). Perteneció a numerosas sociedades norteamericanas y de otros países, habiendo sido presidente de algunas, tales como: American Anthropological Association, Eastern Association on Indian Affairs, y Explorer's Club. Dio conferencias en las universidades de Perú, Chile y Argentina; y fue profesor por intercambio en el Museo Nacional de Antropología y la Universidad Nacional Autónoma de México. Lo designamos miembro honorario de nuestro Seminario de Cultura Maya al ser fundado éste.

En los últimos años, Spinden sólo escribió alguno que otro artículo de menor importancia, pero pudo comprobar el gran desarrollo experimentado por los estudios a que dedicó toda su larga vida. Seguramente tuvo la satisfacción, como parte de una generación de pioneros, de haber contribuido a dar a conocer al mundo distintos aspectos de la brillante civilización de los mayas, y a situar su investigación en un marco cientfífico.

\section{BIBLIOGRAFIA MESOAMERICANISTA}

(Recopilada por Martha Ivon Hernández)

1910. Table showing the chronological sequence of the principal monuments of Copan, Honduras. American Museum of Natural History Journal. New York.

1911. An ancient sepulcher at Placeres del Oro, State of Guerrero, Mexico. American Anthropologist, vol. xiII, pp. 29-55.

1912. The chronological sequence of the principal monuments of Copan (Honduras). Proceedings of the XVII International Congress of Americanists, Mexico 1910, pp. 357-363. México.

1913-a. A study of Maya Art; its subject matter and historical development. Memoirs of the Peabody Museum of Archaeology and 
Ethnology, vol. vI, Harvard University, Cambridge, Massasusetts.

1913-b. The Picture writing of the Aztecs. The American Museum of Natural History Journal, vol. III, p. 31-38. New York.

1914-a. A. Chapter of ancient american History. The American Museum of Natural History Journal, vol. xiv, pp. 16-31. New York.

1914-b. Spinden Expedition. The American Museum of Natural History Journal, vol. xiv, p. 271. New York.

1915-a. Ancient Gold Art in the New World. The American Museum of Natural History Journal, vol. xv, pp. 307-314. New York.

1915-b. Notes on the archaelogy of Salvador. American Anthropologist, n.s. vol. XvII, pp. 446-482. Menasha, Wisconsin.

1916-a. The question of the Zodiac in America. American Anthropologist, n.s., vol. XvirI, $\mathrm{N}^{\circ} 1$, pp. 53-80. Lancaster.

1916-b. Portraiture in central american art. Holmes Anniversary Volu$m e$, pp. 434-450. Washington, D. C.

1917-a. The origin and distribution of agriculture in America. Proceedings of the International Congress of Americanists, nineteenth session, Washington 1915, pp. 269-276. Washington, D. C.

1917-b. Recent progress in the study of Maya Art. Proceedings of the International Congress of Americanists, nineteenth session, Washington 1915, pp. 165-177. Washington, D. C.

1917-c. Ancient Civilizations of Mexico and Central America. American Museum of Natural History, Handbook series, $\mathrm{N}^{\circ} 3$. New York. $\left(2^{*}\right.$ edición $1922,3^{*}$ edición $1928,4^{*}$ edición $1943,5^{n}$ edición 1949).

1917-d. The invention and spread of agriculture in America. American Museum of Natural History Journal, vol. xvir pp. 181-188. New York.

1917-e. On the creater use of Indian foods. The American Museum Journal, tomo xvII, p. 189. New York.

1919-a. The shattered capitals of Central America. The National Geographic Magazine, vol. xxxvI, pp. 185-212. Washington, D. C.

1920. Central American Calendars and the Gregorian day. Proceedings of the National Academy of Sciences 1919, vol. vi, pp. 5659. Washington, D. C.

1920. Sculptures from Yucatan. The American Museum of Natural History, vol. xx, pp. 379-389. New York.

1921. Yellow fever-first and last, its beginning in the wonderful Maya cities of Yucatan which, about $600 \mathrm{~A}$. D., were comparable in civilizations with those of Egypt at its prime. World's Work, vol. XLIII, N $\mathrm{N}^{2}$ 2, pp. 169-181. London.

1922-a. The understudy of Tezcatlipoca. American Indian Life, Parson, E. C. editor, pp. 237-250. Huebsch.

1922-b. The Royal Tombs of Southern Mexico. Brooklyn Museum Quartely, vol. xix, $\mathrm{N}^{\circ} 2$, pp. 56-62. New York.

1923-a. Civilization and the wet tropics. World's Work, vol. xLv, pp. 438-448. 
1923-b. Archaelogical explorations in Honduras. Explorers Journal, tomo II, $\mathrm{N}^{0}$ 2, pp. 7-8. New York.

1923-c. The ancient Art of Mexico. Freeman, vol. vir, 404-405. Irvington, New York.

1923-d. New world correlations. En The XXI Congress of Americanists, Proceedings, pp. 76-86. La Haya, Holanda. Idem. en Psyche, vol. vi, pp. 62-73. Boston, 1926.

1924-a. What about the Indians? World's Work, vol. xLvIr, pp. 377-378.

1924-b. The reduction of Mayan dates. Papers of the Peabody Museum of American Archaeology and Ethnology, vol. vi, $\mathrm{N}^{\circ} 4$. Harvard University, Cambridge.

1925-a. What is Civilization? The answer of Ancient America. En The Forum, vol. Lxxiv, pp. $162-171$ y 371-379.

1925-b. A great american emperor revealed. New York Times Magazine section, diciembre 6, pp. 8-23. Idem. Mexican Life, México, 1926.

1926-a. Archaeology. XVII Mexico and Central America. Enciclopedia Británica, $13^{\natural}$ edición, suplementary, vol. I, pp. 193-196. London.

1926-b. The chorotegan culture area. Proceedings, XXI International Congress of Americanists, Göteborg 1924, pp. 529-554. Göteborg.

1926-c. Maya Architecture: a review of some recent publications. The Arts, vol. xx, pp. 270--277. New York.

1927. A study of the dead city of the "Rubber people". New York Times, mayo $1^{\circ}$ New York.

1927. Importancia de la antigua civilización Maya. Anales de la Sociedad de Geografia e Historia, año III, tomo 3, $\mathrm{N}^{\circ} 4$, pp. 369375. Guatemala. Idem. Revista Municipal, 1928. Guayaquil.

1928-a. Mayas in 538 B. C. Fixed Time exactly by venus calendar. Boston Herald, diciembre 28. Boston.

1928-b. The eclipse table of the Dresden Codex. Proceeding of the XXIII International Congress of Americanists, pp. 140-148. New York.

1928-c. Thank the American Indian. Scientific American, vol. cxxxvirI, $\mathrm{N}^{\circ}$ 4, p. 330-332. New York.

1928-d. Deciphering mayan mysteries. Scientific American, vol. cxxxvirI, $\mathrm{N}^{0} 3$, pp. 232-234. New York.

1928-e. In quest of ruined cities. Scientific American, vol. cxxxvirI, $\mathrm{N}^{\circ}$ 2, pp. 108-111. New York.

1928-f. Ancient mayan astronomy. Scientific American, vol. cxxxvirI, $N^{\circ}$ 1, pp. 8-12. New York.

1928-g. The Inscriptions at Copan. Carnegie Institution, pp. 208-208. Washington, D. C.

1928-h. Maya inscriptions dealing with venus and the moon. Buffalo Society of Natural History, vol. xrv, $\mathrm{N}^{\circ} 1$. Buffalo, New York.

1928-i. The Population of Ancient America. Geographical Review, American Geographical Society, vol. xvirI, N 4, pp. 641-660. New York. 
1929. Fine arts of the mayas. Art and Archaelogy, tomo xxvir, $\mathrm{N}^{\circ}$ 2, pp. 90-91.

1930-a. Maya dates and what they reveal. Brooklyn Institute of Arts and Sciences Museum, Science Bulletin, vol. Iv, N ${ }^{\circ} 1$, p. 110. Brooklyn, New York.

1930-b. Art and Culture of Peru and Mexico; a review of several books. International Studio, vol. xcviI, p. 70.

1930-c. The mystery of the House of the Magician. With Mrs. H. J. Spinden Buffalo Museum of Science, Hobbies, vol. xI, pp. 69-74. Buffalo, New York.

1931-a. Indian symbolism. Introduction to American Indian Art, part. 2, Exposition of Indian Tribal Arts. New York.

1931-b. The language of the Mayas still a challenge to science. New York Times, Sunday, octubre 11. New York.

1931-c. An archaeological junket in Yucatan. Brooklyn Museum Quarterly, vol. xviII, $\mathrm{N}^{\circ} 4$, pp. 133-138. New York.

1932-a. The language of the Mayas. Mexican Life, vol. viII, N 8, pp. 21-60. México.

1932-b. Monte Alban Tomb is rich in promise. New York Times, enero 24. New York.

1932-c. El mapa aéreo del imperio maya. Archivo y Biblioteca Nacional de Honduras, Revista, vol. xI, No. 1-2, pp. 6-11. Honduras.

1933-a. Origin of civilizations in Central America and Mexico. American Aborigines, their origin and antiquity, pp. 217-246. Fifth Pacific Science Congress, Vancouver, Canadá.

1934-a. Crediting Ancient America. The Middle States association of History Teachers, abril, pp. 27-28. New York.

1934-b. Recent archaeological discoveries: in Central America and Mexico The World Today, encyclopedia Británica, tomo $1, \mathrm{~N}^{\circ} 3$, pp. 49-52. London.

? An excursion to Mexico. Brooklyn Museum Quarterly, vol. xxI, No. 4, pp. 81-85. New York. (Escrita con Mrs. H. H. Spinden.)

1935-a. Indian manuscripts of southern México. Anmual report of the Board of the Smithsonian Institution, for the year ending junio de 1933, United States Government Printing Office, pp. 429452. Washington, D.C.

1935-b. Tabular view of maya chronology. Chart. New York.

1935-c. Primitive arts of the old and new worlds. The Brooklyn Museum Quarterly, tomo xxiI, No. 4. Brooklyn, New York.

1935-d. Maya pots and skyscrapers. Three Americas, Nos. 8-26, octubre.

1937-a. Huaxtec sculptures and apotheosis. The Brooklyn Museum Quarterly, vol. xxiv, No. 4, pp. 175-188. New York.

? Jaguar Sky-god. The Brooklyn Museum Quartely, vol. xxiv, No. 4, pp. 179-188. New York.

1937. Los mayas: la primera alta civilización de américa. Boletín de la Unión Panamericana, pp. 709-714. Washington, D.C.

1939. Pottery designs of the Chorotegan. The Brooklyn Museum Bulletin, diciembre 1, vol. $1, \mathrm{~N}^{\circ} 3$. New York. 
1940-a. Art finds a way: the story of human skills. The Brooklyn Museum, New York.

1940-b. Sun worship. Annual report, Smithsonian Institution for 1939, pp. 447-470. Washington, D.C.

1940-c. Diffusion of maya astronomy. The maya and their neighbors, capítulo 11, pp. 162-178. New York y London.

1940-e. Nicaraguan pottery designs by Segueira. Parnassus, vol. XII, $\mathrm{N}^{2} 1$, pp. 20-24. New York.

1940-f. Time scale for the new world. Proceedings, of the eight Scientific Congress, vol. II, pp. 39-44. Washington, D.C.

1942-a. As reveled by art. Catalogue of the exhibition, American South of U.S., The Brooklyn Museum, pp. 1-17. New York.

1942-b. Cronología y cosmología Maya-Tolteca. Mayas y Olmecas, Segunda Reunión de la Mesa Redonda de la Sociedad Mexicana de Antropología, p. 74. México, D. F.

1942-c. Arquitectura Maya. Revista del Museo de la Plata, segunda serie, pp. 133-141. Buenos Aires, Argentina.

1943. La serie suplementaria y la correlación "A". El Norte de México y el Sur de Estados Unidos, Reuniones de Mesa Redonda de la Sociedad Mexicana de Antropología, pp. 311-319. México.

1947. Archaeological sites today. Mexican Life, vol. xxirr, $\mathrm{N}^{\circ} 12$, pp. 19-21 y 61-67. México.

1948-a. New light on Quetzalcoatl. XXVIII Congreso de Americanistas, 1947, pp. 505-512. París, Francia.

1948-b. Mexican calendars and the solar year. Smithsonian Institution, Annual Report for 1948, pp. 393-406. Washington, D.C.

1951. Maya astronomy and the electronic calculator. Homenaje a $\mathrm{Al}$ fonso Caso, pp. 343-352. México.

1956. Los Toltecas en Guatemala. Anales de la Sociedad de Geografía e Historia de Guatemala, vol. xxix, pp. 18-23. Guatemala.

1957-a. Maya Art and Civilization. The Falcon's Wing Press, Indian Hills, Colorado.

1957-b. Art of the Maya Civilization. Exhibition at the Martin Widdifield gallery, 20 páginas, 22 ilustraciones. New York. 


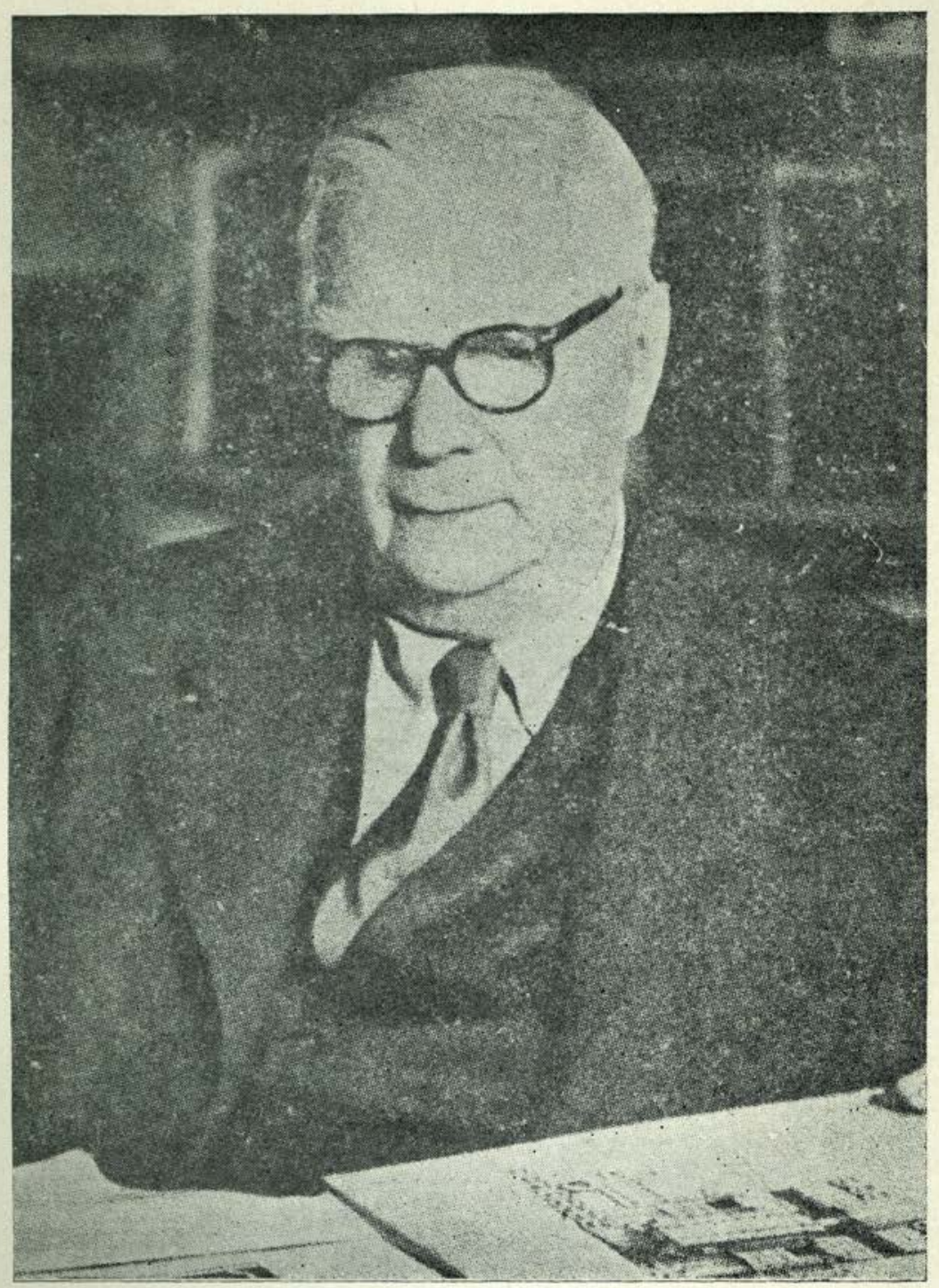

Estudios de Cultura Maya. Vol. VIII, 1970

Facultad de Filosofía y Letras/Coordinación de Humanidades

Centro de Estudios Mayas, UNAM

http://www.iifilologicas.unam.mx/estculmaya/ 